TERNATIONAL

\title{
Mechanical properties of sugar beet root during storage ${ }^{* *}$
}

\author{
Š́rka Nedomová ${ }^{1}$, Vojtěch Kumbár ${ }^{2}$, Roman Pytel ${ }^{1}$, and Jaroslav Buchar ${ }^{2}$ \\ ${ }^{1}$ Department of Food Technology, ${ }^{2}$ Department of Technology and Automobile Transport (section physics) \\ Mendel University in Brno, Zemědělská 1, 61300 Brno, Czech Republic
}

Received January 9, 2017; accepted August 9, 2017

\begin{abstract}
This paper is an investigation via two experimental methods, of the textural properties of sugar beet roots during the storage period. In the work, sugar beet roots mechanical properties were evaluated during the post-harvest period -1 , $8,22,43$, and 71 days after crop. Both experimental methods, i.e. compression test and puncture test, suggest that the failure strength of the sugar beet root increases with the storage time. The parameters obtained using the puncture test, are more sensitive to the storage duration than those obtained by way of the compression test. We also found that such mechanical properties served as a reliable tool for monitoring the progress of sugar beet roots storage. The described methods could also be used to highlight important information on sugar beet evolution during storage.

Keyw ords: sugar beet root, texture, compression, puncture, storage
\end{abstract}

\section{INTRODUCTION}

Sugar beet (Beta vulgaris L.) is the world's most cultivaed crop after sugarcane (Saccharum officinarum L.) or the production of sucrose for human consumption. The mechanical properties of the beet, together with sucrose, soluble solids and moisture content, are important parameters in evaluating the sucrose yield and the cost of sugar beet production, and also for assessing new sugar beet germplasms and/or cultivars (Cheng et al., 2011; Kabas and Ozmerzi, 2008; Kertész et al., 2015; Kumbár et al., 2015). Most of these properties are evaluated through compression, rheological and puncture testing (Sirisomboon et al., 2012; Szymanek, 2009; Trávníček et al., 2016; Trnka et al., 2016). The compression test is effective in evaluating the mechanical response of the whole agricultural product, while the puncture test is useful in indicating the approxi-

\footnotetext{
*Corresponding author e-mail: vojtech.kumbar@mendelu.cz **This research was primarily supported and financed by project TP 2/2017 "Effect of additives on the rheological behaviour of foodstuffs and raw materials for their production", of the Internal Grant Agency FA MENDELU.
}

mate strength of the peel and the flesh at the puncture point (Nedomová et al., 2016). These two tests are also effective in testing for most of the categories of damage to fruit and vegetables (Sirisomboon and Pornchaloempong, 2011). In addition, such tests provide useful data for engineers which can be utilized in the design of postharvest handling machines and equipment for fruit and vegetables, such as that for sorting, grading, packing and conveying, as well as for designing storage systems (Božiková and Hlaváč, 2016; García-Ramos et al., 2003).

The aim of this paper is to investigate the textural properties of sugar beet root during the storage period. Herein, both of the aforementioned methods are utilized.

\section{MATERIAL AND METHODS}

The sugar beets used in this study were collected from a field near Jiř́k kovice (region South Moravia) during the 2015 harvest season. The sugar beet variety was Gellert, which is a species-tolerant diploid variety, NC type, suitable for early harvesting. The variety is resistant to flowering, but less resistant to leaf spot complexes (Hakaufová, 2013). Exactly 100 sugar beet roots samples were placed in refrigerated storage at $4^{\circ} \mathrm{C}$ and $85 \%$ relative humidity prior to the experiment.

Cylindrical samples with a diameter of $10 \mathrm{~mm}$ were cut from the central region of each beet using a cork borer, then were trimmed to the height of $12 \mathrm{~mm}$. The specimens were compressed between two steel plates. The crosshead velocity was $20 \mathrm{~mm} \mathrm{~min}^{-1}$. The mechanical properties assessment was conducted using TIRATEST 27025 (TIRA Maschinenbau $\mathrm{GmbH}$, Germany). This equipment enables both compression, as well as puncture testing (Nedomová et al., 2016).

(C) 2017 Institute of Agrophysics, Polish Academy of Sciences 
Mechanical testing of material by means of the uniaxial compression test is basically very simple (Atluri and Kobayashi, 1993). A cylindrical sample of height $l_{o}$ and cross section $A_{o}$ is compressed between two parallel metal plates at a fixed crosshead speed. The force $F$ and the deformation $\Delta l$ are measured during this compression, and both quantities are recorded. The generated force-deformation data may be easily transformed into normalized quantities such as stress and strain. The Cauchy or engineering strain and Hencky's natural or 'true' strain are commonly used in representing compression curves (Peleg, 1984). The Cauchy's strain measure $\varepsilon_{C}$ gives the relative deformation with respect to the initial sample height $l_{o}$ (Liu and Krempl, 1979):

$$
\varepsilon_{C}=\frac{\Delta l}{l_{0}} .
$$

Hencky's strain $\varepsilon_{H}$ (often denoted as 'true' strain) derives from the integration of the infinitesimal strain $-\frac{d l}{l}$ and reads (Plešek and Kruisová, 2006):

$$
\varepsilon_{\mathrm{H}}=-\ln \left(\frac{l_{0}-\Delta l}{l_{0}}\right)=-\ln \left(1-\varepsilon_{\mathrm{C}}\right) .
$$

The force $F$ can be converted to the ultimate or engineering stress $\sigma_{u}$ or to the true stress $\sigma_{c}$. The ultimate stress is simply given as:

$$
\sigma_{u}=\frac{F}{A_{0}} .
$$

The true stress is evaluated using the instantaneous cross section $A$. Its value is mostly obtained through assuming a constant volume of the specimen (Casiraghi et al., 1985):

$$
V=V_{0} \Leftrightarrow A l=A_{0} l_{0} A=A_{0} \frac{l_{0}}{l-\Delta l},
$$

The true stress is then expressed as (Čadek et al., 2004):

$$
\sigma_{C}=\frac{F}{A}=\frac{F}{A_{0}} \frac{l_{0}-\Delta l}{l_{0}}=>\sigma_{C}=\sigma_{u}\left(1-\varepsilon_{C}\right)
$$

The puncture test is the most common method for assessing fruit and vegetables texture characteristics (Juxia et al., 2015; Nannyonga et al., 2016; RodriguezArcos et al., 2002). It measures firmness (Duprat et al., 1995). A typical penetration curve is shown in Fig. 1 (Camps et al., 2005).

The maximal force $F_{s}$ represents the force required to puncture the fruit skin. Herein, $F_{s}$ is the skin strength. If the dependence force-displacement is linear, the slope of the penetration curve defines the stiffness $S_{\text {sitf }}=\frac{F_{S}}{D_{p}}$

(Okamura et al., 2004). Work $W_{l}$ is the mechanical work needed to reach the rupture point. The flesh firmness $F_{f}$ is the average values of the forces measured after the skin rupture (Altuntas and Karaosman, 2015; Ozturk et al., 2009). In a similar way, work $W_{2}$ is the work measured after the skin rupture.

Analysis of variance (ANOVA) was applied to all variables studied. Mean values obtained in the different measurements were compared by one-way analysis of variance (ANOVA). Statistical analysis was performed with the statistical toolbox of software Matlab version 7.12.0.635 (R 2011a) (The MathWorks, Inc., Nattick, MA).

\section{RESULTS AND DISCUSSION}

In the compression testing, an example of the experimental record force-displacement is displayed in Fig. 2. This record $F(\Delta l)$ can be converted to the stress strain dependence as described in Eqs (1) - (5). Stress increases with the strain up to some maximum. This maximum corresponds to the tissue damage. Owing to this fact, this stress is denoted as the failure stress. The same qualitative features exhibit the stress-strain curves during the whole period of the storage (Fig. 3).

Four parameters were identified so as to characterise the compression stress-strain curves (Canet et al., 2005; Luginbühl, 1996; Smith and Kobayashi, 1993). These are:

- the failure stress;

- the Cauchy strain at stress maximum $\varepsilon_{C}$;

- the Hencky strain at stress maximum $\varepsilon_{H}$;

- the apparent energy density at the failure. This is defined as the total work of deformation divided by the original sample volume $W=\int_{0}^{\varepsilon_{C}} \sigma_{u} d \varepsilon\left(\mathrm{J} \mathrm{m}^{-3}\right)$ (Náhlík et al., 2016).

All these parameters are given in Table 1. The data are presented as mean value from 5 measurements \pm standard deviation.

The maximum of the stress increases with the duration of the storage as in Molenda et al. (2002). The same can be observed for the corresponding strain. The changes in the energy $W$ with the storage duration are not too significant (Fig. 4).

In the puncture testing, we obtained a force-penetration depth dependence which is denoted as the penetration curve (Marshall et al., 2008; Oraguzie et al., 2007; Wen et al., 2006). This method has been used for the evaluation of fruit quality (de Escalada Pla et al., 2006; Forney, 2008; Harker et al., 2002; Ruiz et al., 2005; Wu and Abott, 2002). With this test, the maximal penetration force is measured that is required to let a cylindrical probe penetrate, e.g. in the apple, flesh up to a predetermined depth (Bianchi et al., 2016; Mehinagic et al., 2003; Valdez-Fragoso et al., 2009).

Puncture tests were performed on the samples using the same testing device, i.e. the TIRATEST 27025. A stainless steel plunger with a flat end diameter of $6 \mathrm{~mm}$ was 


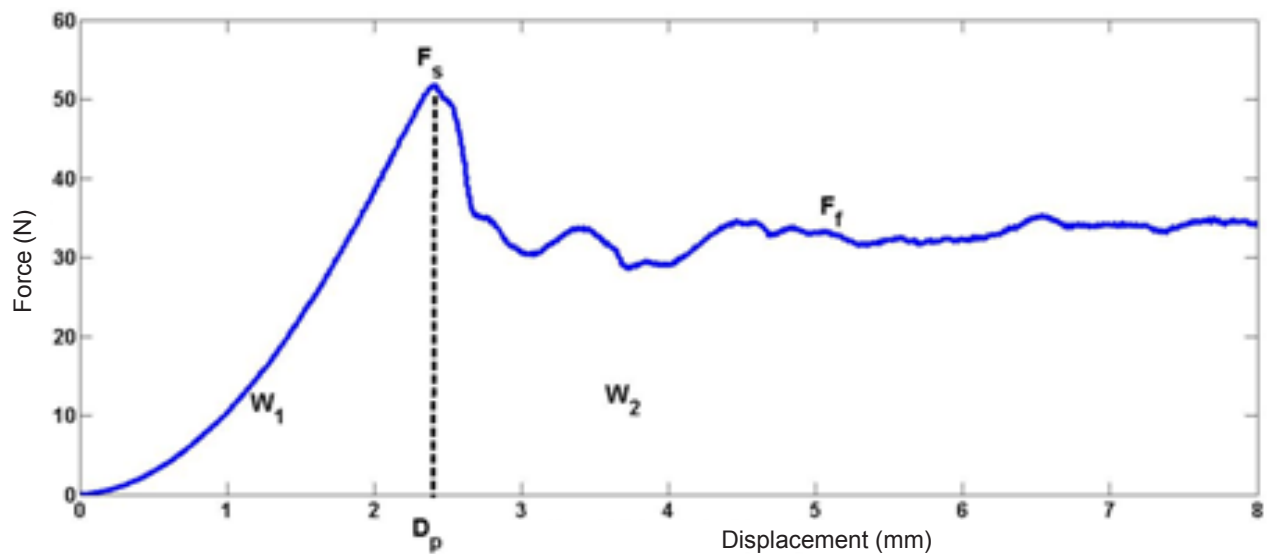

Fig. 1. Typical course of the force-displacement curve during the puncture test.

a

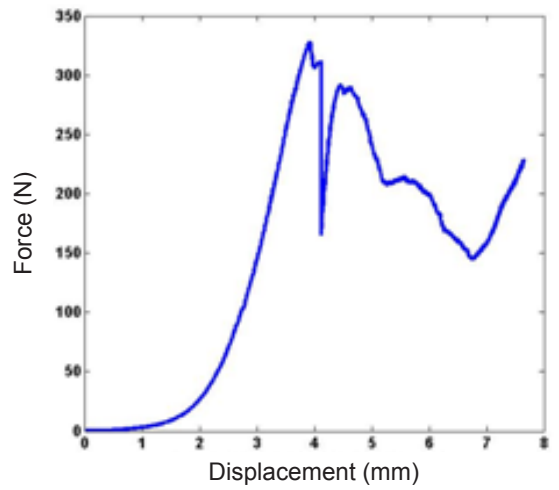

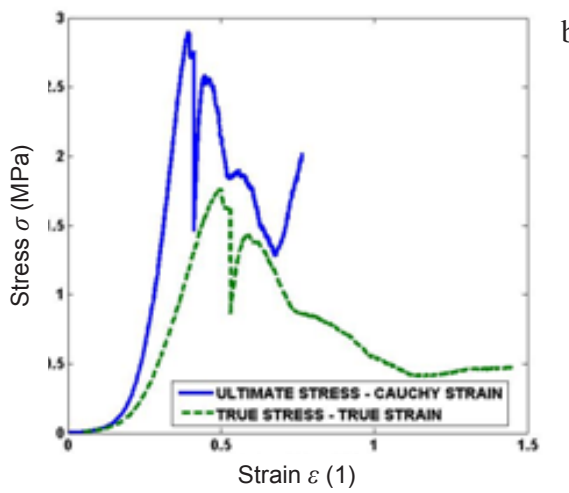

Fig. 2. Example of the experimental record: $a$ - force-displacement and b-stress-strain dependence.

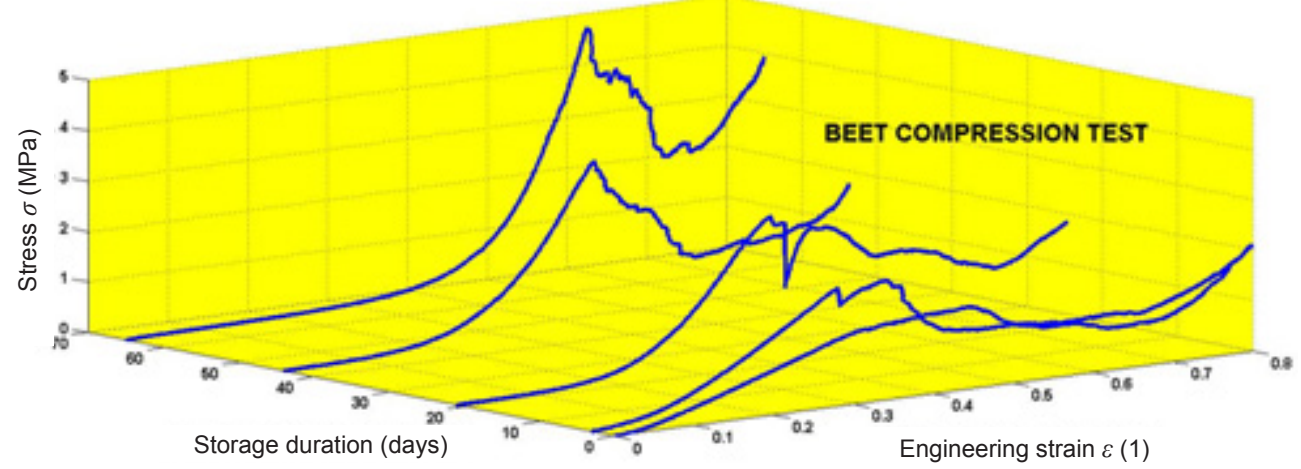

Fig. 3. Stress-strain curves during the storage period.

Table 1. Main parameters of the compression stress-strain curves

\begin{tabular}{ccccc}
\hline Storage (days) & $\sigma_{\max }(\mathrm{MPa})$ & $\varepsilon_{\mathrm{C}}$ & $\varepsilon_{\mathrm{H}}$ & $W\left(\mathrm{MJ} \mathrm{m}^{-3}\right)$ \\
\hline 1 & $2.08 \pm 0.388 \mathrm{a}$ & $0.316 \pm 0.0554 \mathrm{a}$ & $0.372 \pm 0.0754 \mathrm{a}$ & $1.035 \pm 0.1930 \mathrm{a}$ \\
8 & $2.34 \pm 0.496 \mathrm{ab}$ & $0.276 \pm 0.0229 \mathrm{a}$ & $0.318 \pm 0.0312 \mathrm{a}$ & $1.141 \pm 0.0897 \mathrm{ab}$ \\
22 & $2.48 \pm 0.352 \mathrm{~b}$ & $0.312 \pm 0.0030 \mathrm{a}$ & $0.366 \pm 0.0041 \mathrm{a}$ & $0.950 \pm 0.1638 \mathrm{a}$ \\
43 & $2.81 \pm 0.394 \mathrm{a}$ & $0.308 \pm 0.0210 \mathrm{a}$ & $0.360 \pm 0.0287 \mathrm{a}$ & $0.803 \pm 0.0573 \mathrm{ac}$ \\
71 & $3.69 \pm 0.206 \mathrm{c}$ & $0.349 \pm 0.0165 \mathrm{~b}$ & $0.417 \pm 0.0234 \mathrm{~b}$ & $1.090 \pm 0.2407 \mathrm{a}$ \\
\hline
\end{tabular}

*Different letters in the same column for each source indicate significant differences in means, $\mathrm{N}=5, \mathrm{p} \leq 0.01$. 

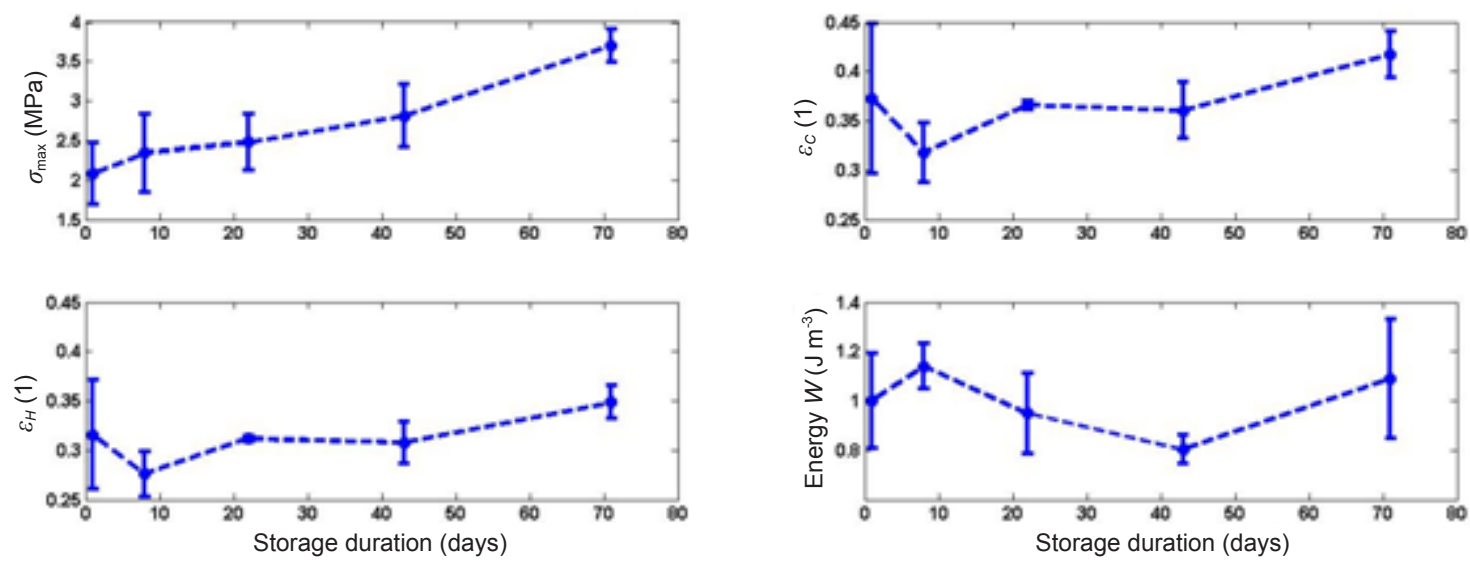

Fig. 4. Effect of the storage duration on the main parameters of the compression stress-strain curve.

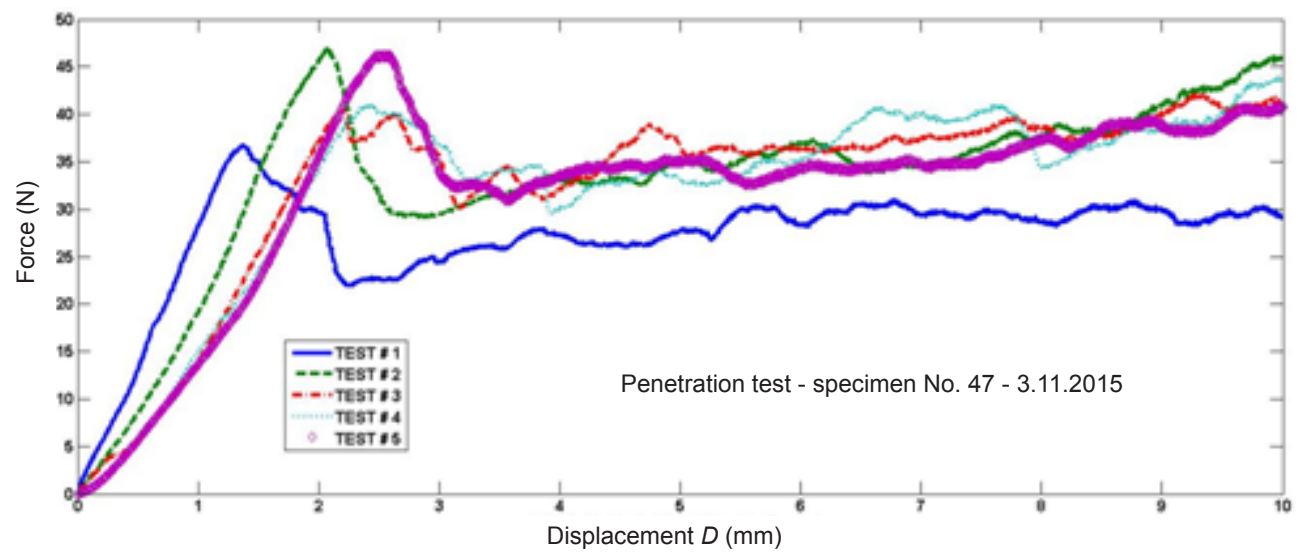

Fig. 5. Experimental records force - displacement (1st day of the storage).

Table 2. Parameters of the puncture test

\begin{tabular}{cccc}
\hline Storage (days) & $D_{p}(\mathrm{~mm})$ & $F_{s}(\mathrm{~N})$ & $W_{1}(\mathrm{Nmm})$ \\
\hline 1 & $2.087 \pm 0.5752 \mathrm{a}$ & $35.16 \pm 5.443 \mathrm{a}$ & $133.00 \pm 9.491 \mathrm{a}$ \\
8 & $2.455 \pm 0.3904 \mathrm{a}$ & $47.56 \pm 3.975 \mathrm{~b}$ & $142.89 \pm 29.082 \mathrm{a}$ \\
22 & $3.812 \pm 0.6106 \mathrm{~b}$ & $45.07 \pm 7.165 \mathrm{~b}$ & $154.27 \pm 46.705 \mathrm{a}$ \\
43 & $4.524 \pm 0.8521 \mathrm{~b}$ & $50.16 \pm 6.445 \mathrm{bc}$ & $197.74 \pm 32.215 \mathrm{~b}$ \\
71 & $6.833 \pm 0.9741 \mathrm{c}$ & $56.16 \pm 10.2 \mathrm{c}$ & $349.13 \pm 47.892 \mathrm{c}$ \\
\hline
\end{tabular}

Explanations as in Table 1.

attached to the load cell and used to penetrate the fruit at a deformation speed of $20 \mathrm{~mm} \mathrm{~min}{ }^{-1}$. An example of the obtained experimental data (the penetration curves and force-displacements) is shown in Fig. 5.

It is evident that the results of our experimental work exhibit the main features displayed in Fig. 1. The main parameters of this dependence, i.e. skin strength $F_{s}$ corre- sponding displacement $D_{p}$ and energy $W_{1}=\int_{0}^{D_{p}} F d D$ are given in Table 2. The dependence of these parameters is displayed in Figs 6-8.

Our work indicates that all the described parameters increase with the duration of the storage (Miraei Ashtiani et al., 2016; Nedomová et al., 2016, 2017). 


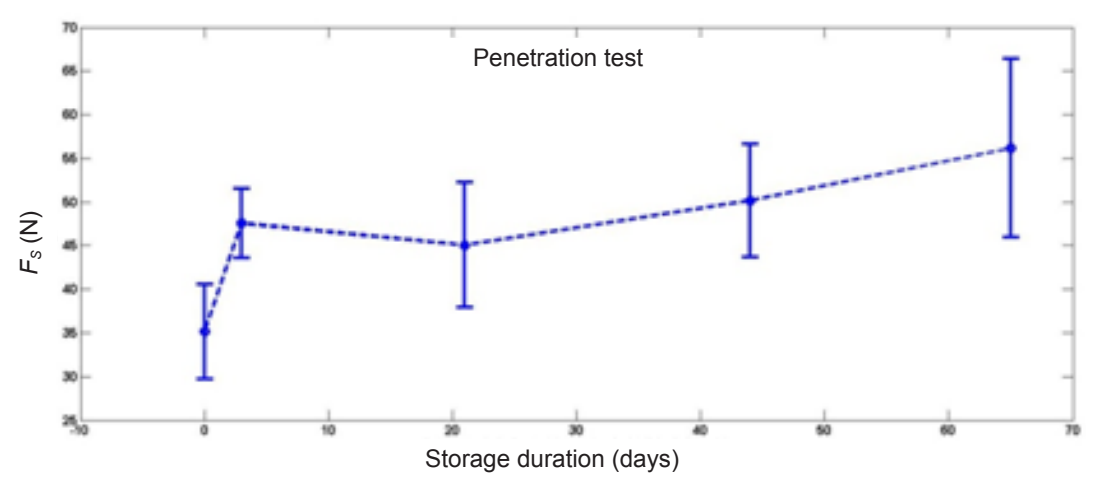

Fig. 6. Effect of the storage duration on the skin strength.

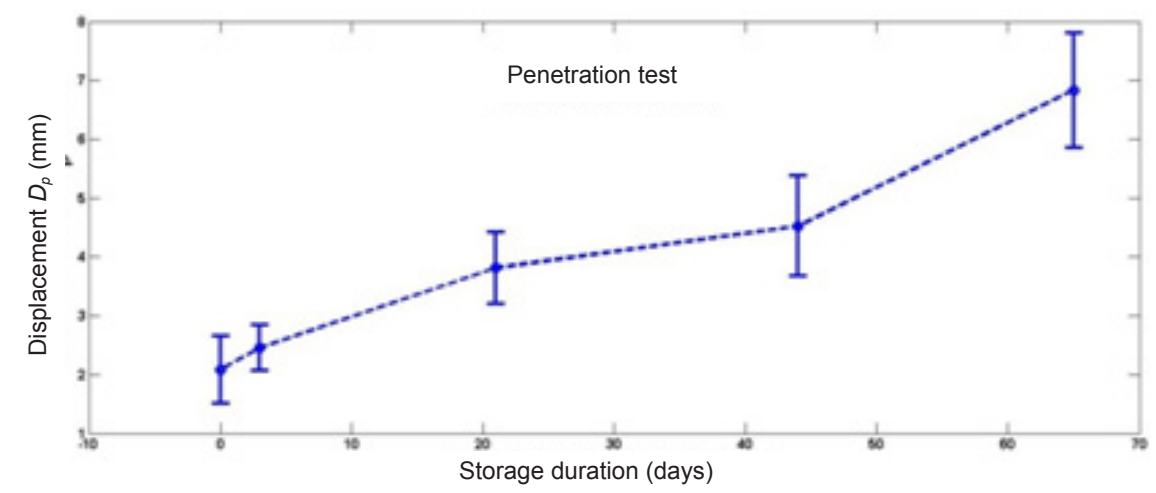

Fig. 7. Effect of the storage duration on the penetration depth at the rupture point.

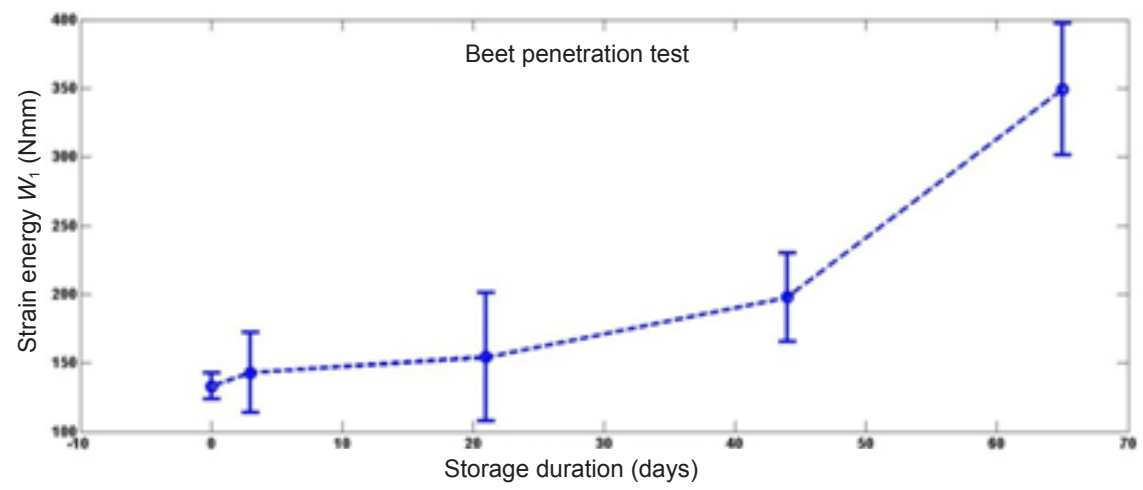

Fig. 8. Effect of the storage duration on the work up to the rupture point.

\section{CONCLUSIONS}

1. Sugar beet failure strength increases with the storage time.

2. The changes in mechanical parameters of sugar beet roots during storage time can be described better through the compression test than by way of the puncture test.

3 . The described methods can be used for determination mechanical properties during sugar beet processing (e.g. crop, transport, root wash, mechanical strip slicing).

Conflict of interest: The Authors do not declare conflict of interest.

\section{REFERENCES}

Altuntas E. and Karaosman N., 2015. Post-harvest engineering properties of japan flowering crabapple (malus floribunda) fruits. Agric. Eng. Int.: CIGR J., 17(1), 264-272.

Atluri S.N. and Kobayashi A.S., 1993. Mechanical Responses of Materials. In: Handbook on Experimental Mechanics (Ed.

A.S. Kobayashi). VCH Publishers, New York.

Bianchi T., Guerrero L., Gratacós-Cubarsí M., Claret A., Argyris J., Garcia-Mas J., and Hortós M., 2016. Textural properties of different melon (Cucumis melo L.) fruit types: Sensory and physical-chemical evaluation. Scientia Horticulturae, 201, 46-56. 
Božiková M. and Hlaváč P., 2016. Thermal properties of selected cheeses samples. J. Central Eur. Agric., 17(1), 63-74.

Camps C., Guillermin P., Mauget J.C., and Bertrand D., 2005. Data analysis of penetrometric force/displacement curves for characterization of whole apple fruits. J. Texture Studies, 36(4), 387-401.

Canet W., Alvarez M.D., and Fernández C., 2005. Optimization of low-temperature blanching for retention of potato firmness: effect of previous storage time on compression properties. Eur. Food Res. Technol., 221(3), 423-433.

Casiraghi E.M., Bagley E.B., and Christianson D.D., 1985. Behaviour of Mozzarella, Cheddar and processed cheese spread in lubricated and bonded uniaxial compression. J. Texture Studies, 16, 281-301.

Cheng D., Cui J., Luo C., Liu Q., Shi S., Lu Z., and Kobo T., 2011. Molecule studying on the diversity of cytoplasm fertility in chinese sugar beet germplasm resource. Int. Conf. Remote Sensing, Environment and Transportation Engineering (RSETE), June 24-26, Nanjing, China.

Čadek J., Kuchařová K., and Milička K., 2004. Creep in copper dispersion strengthened with fine alumina particles and reinforced with alumina short fibres - an ODS copper matrix composite. J. Alloys Compounds, 378(1-2), 123-126.

de Escalada Pla M., Delbon M., Rojas A.M., and Gerschenson L.N., 2006. Effect of immersion and turgor pressure change on mechanical properties of pumpkin (Cucumis moschata, Duch.). J. Sci. Food Agric., 86(15), 2628-2637.

Duprat F., Grotte M.G., Pietri E., and Studman C.J., 1995. A multi-purpose firmness tester for fruits and vegetables. Computers Electronics Agric., 12(3), 211-223.

Forney F.CH., 2008. Optimizing the storage temperature and humidity for fresh cranberries: a reassessment of chilling sensitivity. HortScience, 43(2), 439-446.

García-Ramos F.J., Ortiz-Cañavate J., and Ruiz-Altisent M., 2003. Reduction of mechanical damage to apples in a packing line using mechanical devices. Appl. Eng. Agric., 19(6), 703-707.

Hakaufová L., 2013. Sugar beet varieties registered in 2013. Listy Cukrovarnické a Řepařské, 129(2), 46-52.

Harker F.R., Maindonald J., Murray S.H., Gunson F.A., Hallett I.C., and Walker S.B., 2002. Sensory interpretation of instrumental measurements 1: texture of apple fruit. Postharvest Biol. Technol., 24(3), 225-239.

Juxia W., Qingliang C., Hongb L., and Yaping L., 2015. Experimental research on mechanical properties of apple peels. J. Eng. Technol. Sci., 47(6), 688-705.

Kabas O. and Ozmerzi A., 2008. Determining the mechanical properties of cherry tomato varieties for handling. J. Texture Studies, 39(3), 199-209.

Kertész Á., Hlaváčová Z., Vozáry E., and Staroňová L., 2015. Relationship between moisture content and electrical impedance of carrot slices during drying. Int. Agrophys., 29(1), 61-66.

Kumbár V., Votava J., and Nedomová Š., 2015. Influence of storage time, initial mass and circumference on weight and size disposals of sugar beet. Listy Cukrovarnické a Řepařské, 131(11), 334-337.

Liu M.C.M. and Krempl E., 1979. A uniaxial viscoplastic model based on total strain and overstress. J. Mechanics Physics Solids, 27(5-6), 377-391.
Luginbühl W., 1996. The effect of stress correction on fracture point coordinates in uniaxial compression tests of cheese. LWT - Food Sci. Technol., 29(5-6), 433-437.

Marshall D.A., Spiers J.M., and Stringer S.J., 2008. Blueberry splitting tendencies as predicted by fruit firmness. HortScience, 43(2), 567-570.

Mehinagic E., Royer G., Bertrand D., Symoneaux R., Laurens F., and Jourjon F., 2003. Relationship between sensory analysis, penetrometry and visible-NIR spectroscopy of apples belonging to different cultivars. Food Quality Preference, 14(5-6), 473-484

Miraei Ashtiani S.H., Golzarian M.R., Baradaran Motie J., Emadi B., Nikoo Jamal N., and Mohammadinezhad H., 2016. Effect of loading position and storage duration on the textural properties of eggplant. Int. J. Food Properties, 19(4), 814-825.

Molenda M., Montross M.D., Horabik J., and Ross I.J., 2002. Mechanical properties of corn and soybean meal. Trans. American Society Agric. Eng., 45(6), 1929-1936.

Nannyonga S., Bakalis S., Andrews J., Mugampoza E., and Gkatzionis K., 2016. Mathematical modelling of color, texture kinetics and sensory attributes characterisation of ripening bananas for waste critical point determination. J. Food Eng., 190, 205-210.

Náhlík L., Štegnerová K., Máša B., and Hutař P., 2016. A failure scenario of ceramic laminates with strong interfaces. Eng. Fracture Mechanics, 167, 56-67.

Nedomová Š., Kumbár V., Pavloušek P., Pytel R., Lampír L., and Buchar J., 2017. Effect of harvest date on composition and geometry of grape berries. Eur. J. Horticultural Sci., 82(1), 21-30.

Nedomová Š., Kumbár V., Pavloušek P., Pytel R., Začal J., and Buchar J., 2016. Influence of harvest day on changes in mechanical properties of grape berries. Potravinarstvo, 10(1), 181-187.

Oraguzie N.C., Volz R.K., Whitworth C.J., Bassett H.C.M., Hall A.J., and Gardiner S.E., 2007. Influence of Md-ACS1 allelotype and harvest season within an apple germplasm collection on fruit softening during cold air storage. Postharvest Biology Technol., 44(3), 212-219.

Ozturk I., Ercisli S., Kalkan F., and Demir B., 2009. Some chemical and physico-mechanical properties of pear cultivars. African J. Biotechnol., 8(4), 687-693.

Peleg M., 1984. A note on the various strain measures at large compressive deformations. J. Texture Studies, 15(4), 317-326.

Plešek J. and Kruisová A., 2006. Formulation, validation and numerical procedures for hencky's elasticity model. Computers Structures, 84(17-18), 1141-1150.

Rodriguez-Arcos R.C., Smith A.C., and Waldron K.W., 2002. Mechanical properties of green asparagus. J. Sci. Food Agric., 82(3), 293-300.

Ruiz D., Egea J., Tomás-Barberán F.A., and Gill M.I., 2005. Carotenoids from new apricot (Prunus armeniaca L.) varieties and their relationship with flesh and skin color. J. Agric. Food Chemistry, 53(16), 6368-6374.

Sirisomboon P. and Pornchaloempong P., 2011. Instrumental textural properties of mango (CV NAM DOC MAI) at commercial harvesting time. Int. J. Food Properties, 14(2), 441-449. 
Sirisomboon P., Tanaka M., and Kojima T., 2012. Evaluation of tomato textural mechanical properties. J. Food Eng., 111(4), 618-624.

Smith C.V. and Kobayashi A.S., 1993. Experimental fracture mechanics. In: In: Handbook on Experimental Mechanics (Ed. A.S. Kobayashi). VCH Publishers, New York.

Szymanek M., 2009. Influence of sweet corn harvest date on kernels quality. Res. Agric. Eng., 55(1), 10-17.

Thiagu R., Chand N., and Ramana K.V.R., 1993. Evolution of mechanical characteristics of tomatoes of two varieties during ripening. J. Sci. Food Agric., 62(2), 175-183.

Okamura A.M., Simone C. and O'Leary, 2004. Force modeling for needle insertation into soft tissue. IEEE Transact. Biomed. Eng., 51(10), 1707-1716.

Trávníček P., Burg P., Krakowiak-Bal A., Junga P., Vítěz T., and Ziemiańczyk U., 2016. Study of rheological behaviour of wines. Int. Agrophys., 30(4), 509-518.
Trnka J., Pavloušek P., Nedomová Š., and Buchar J., 2016. Time and frequency domain response of grape berries to nondestructive impact during the harvesting period. J. Texture Studies, 47(1), 24-33.

Valdez-Fragoso A., Soto-Caballero M.C., Blanda G., WeltiChanes J., and Mújica-Paz H., 2009. Firmness changes of impregnated whole peeled prickly pear. J. Texture Studies, 40(5), 571-583.

Wen Q., Ma R., Dong Q., and Xin Y., 2006. Studies on postharvest physiology and the storage technology of mango (Mangifera indica L.). J. Food Proc. Preservation, 30(6), 670-683.

Wu T. and Abott J.A., 2002. Firmness and force relaxation characteristics of tomatoes stored intact or as slices. Postharvest Biol. Technol., 24(1), 59-68. 